\title{
The nomenclatural status of \\ Palaeothrissum inaequilobum BLAINVILE, 1818, \\ P. parvum Blatnviue, 1818, and Aeduella blainvillei (AgASSZ, 1833) \\ (Actinopterygii, Aeduellidae)
}

\begin{abstract}
Arnaud BRIGNON ${ }^{1}$
Abstract: It is shown that the species names Palaeothrissum inaequilobum BLAINVILLE, 1818, and $P$. parvum Blainville, 1818, from the Lower Permian (Asselian) of Muse, near Autun (Saône-et-Loire department, France) are senior synonyms of the widely used species name, Aeduella blainvillei (AGASSIz, 1833). In the interest of nomenclatural stability, conditions exist which allow reversal of precedence as stated in Article 23.9.1 of the International Code of Zoological Nomenclature. Thus the species name Aeduella blainvillei (AGASSIZ, 1833) is regarded as valid, qualifying as a nomen protectum, whereas Palaeothrissum inaequilobum BLAINVILLE, 1818, and P. parvum BLAINVILLE, 1818, are invalid, qualifying as nomina oblita. Some of the specimens from the type series upon which $P$. inaequilobum, $P$. parvum and Aeduella blainvillei were erected, are identified.
\end{abstract}

\section{Key-words:}

- Aeduellidae;

- Aeduella;

- Permian;

- Asselian;

- Autunian;

- reversal of precedence

Citation: BRIGNON A. (2019).- The nomenclatural status of Palaeothrissum inaequilobum BLAINVILLE, 1818, P. parvum Blainville, 1818, and Aeduella blainvillei (AgASSIZ, 1833) (Actinopterygii, Aeduellidae).- Carnets Geol., Madrid, vol. 19, no. 8, p. 141-148.

Résumé : Statut nomenclatural de Palaeothrissum inaequilobum BLAINVILLE, 1818, P. parvum BLAINville, 1818, et Aeduella blainvillei (AGASSIZ, 1833) (Aeduelliformes, Aeduellidae). - Il est montré que les noms spécifiques Palaeothrissum inaequilobum BLAINVILLE, 1818, et $P$. parvum BLAINVILLE, 1818, du Permien inférieur (Assélien) de Muse, près d'Autun (Saône-et-Loire, France) sont des synonymes plus anciens de l'espèce largement utilisée, Aeduella blainvillei (AgASSIZ, 1833). Afin de maintenir la stabilité nomenclaturale, les conditions sont cependant réunies pour une inversion de préséance en accord avec l'article 23.9.1 du Code International de Nomenclature Zoologique. Le nom spécifique Aeduella blainvillei est ainsi considéré comme valide et est qualifié de nomen protectum, alors que Palaeothrissum inaequilobum BLAINVILLE, 1818, et $P$. parvum BLAINVILLE, 1818, sont invalides et qualifiés de nomina oblita. Quelques spécimens des séries types sur lesquelles furent créées les espèces $P$. inaequilobum, $P$. parvum et Aeduella blainvillei, sont identifiés.

Mots-clefs :

- Aeduellidae ;

- Aeduella ;

- Permien :

- Assélien ;

- Autunien ;

- inversion de préséance

15 villa Jeanne d'Arc, 92340 Bourg-la-Reine (France) arnaud.brignon@yahoo.com

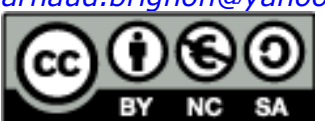

Published online in final form (pdf) on August 8, 2019

[Editor: Bruno GRANIER; language editor: Stephen CAREY] 


\section{Introduction}

Muse (Saône-et-Loire department, France), near Autun, is a well-known Lower Permian vertebrate-bearing fossiliferous site (GAND et al. 2011 , 2017). The Muse Formation is part of the regional continental Autunian stratotype that corresponds to the Asselian stage (FALCONNET, 2014). The history of the early fossil fish discoveries in this locality has recently been detailed (BRIGNON, 2014). In 1818, Henri-Marie DUCROTAY de BLAINVILLE $(1818 a$, p. $321 ; 1818 b$, p. 17) was the first to describe, without illustration, two new species of fossil fishes from the surroundings of Autun. These species, Palaeothrissum inaequilobum BLAINVILLE, 1818, and $P$. parvum BLAINVILLE, 1818, were accompanied by brief descriptions and are available according to Articles 11 and 12.1 of the International Code of Zoological Nomenclature (ICZN, 1999). They were based upon specimens in the collections of Barthélémy FAUJAS de SAINTFOND (1741-1819) and Alexandre BRONGNIART (1770-1847). In the same publication, BLAINVILLE (1818a, p. 393; 1818b, p. 89) indicated that all the specimens were collected in Muse by Cyprien Prosper BRARD (1786-1838) and François-Joseph LAINÉ (1778-1836). The latter reported that the first fishes from Muse where discovered in 1811 (BRIGNON, 2014).

Thereafter, in the first "livraison" of his "Recherches sur les poissons fossiles", AGASSIZ (1833) introduced three new species of fossil fishes from Muse, namely Palaeoniscum blainvillei, Palaeoniscum voltzii and Palaeoniscum angustum, assigning them to the genus Palaeoniscum BLAINVILLE, 1818, with the incorrect subsequent spelling Palaeoniscus (ICZN, 1999, article 33.3). In his original description, AgAssiz (1833) explicitly synonymized Palaeoniscum blainvillei with Palaeothrissum inaequilobum BLAINVILLE, 1818, and Palaeothrissum parvum BLAINVILLE, 1818. Although the two latter names are objective senior synonyms of the first one, WESTOLL (1937) retained Palaeoniscum blainvillei as the type species by monotypy of his newly erected genus Aeduella. Since then, Aeduella blainvillei (AGASSIZ, 1833) has been considered as valid despite the priority of Palaeothrissum inaequilobum BLAINVILLE, 1818, and Palaeothrissum parvum BLAINVILLE, 1818. This paper aims at clarifying this nomenclatural issue.

\section{Historical overview}

In addition to Palaeothrissum inaequilobum and Palaeothrissum parvum, BLAINVILLE (1818a, $1818 \mathrm{~b})$ also placed in the genus Palaeothrissum two other species, $P$. macrocephalum BLAINVILLE, 1818, and $P$. magnum BLAINVILLE, 1818, both from the Kupferschiefer (Upper Permian) of Germany. AgAssiz (1833, vol. 2, p. 5) showed that Palaeothrissum macrocephalum was a subjective synonym of Palaeoniscum freieslebeni BLAINVILLE,
1818. As outlined in the introduction, AGASSIZ (1833, vol. 2, p. 4) placed Palaeothrissum inaequilobum and Palaeothrissum parvum in the genus Palaeoniscum BLAINVILLE, 1818. AgASSIZ (1833, p. 10) noted that Palaeothrissum magnum BLAINVILLE, 1818, should not be confused with Palaeoniscum magnum AGASSIZ, 1833, erroneously written Palaeoniscus magnus by AgAssiz (1833, vol. 2, p. 5; 1834, vol. 2, p. 78-80), a species also from the Upper Permian of Germany. He stated that Palaeothrissum magnum BLAINVILLE, 1818 , belongs to his newly erected genus, Pygopterus AGASSIZ, 1833. As the first reviser, AGASSIZ established that the genus Palaeothrissum is a synonym of Palaeoniscum (AGASSIz, 1833, vol. 2, p. 4; WOODWARD, 1891).

In his Handbuch der Petrefaktenkunde, QUENSTEDT (1852, p. 225) gave priority to "Palaeoniscus" inaequilobus over "Palaeoniscus" blainvillei. Considering Palaeoniscum blainvillei to be a valid name, TRAQUAIR (1877) suggested that this species may be the type of yet another genus. Later, SAUVAGE (1890) restored the priority of the species name "Palaeothrissum" inaequilobum over Palaeoniscum blainvillei and assigned the former to the genus Amblypterus AGASSIZ, 1833. According to SAUVAGE, the new combination Amblypterus inaequilobum (BLAINVILLE, 1818) included the objective junior synonym Palaeoniscum blainvillei and the subjective synonym "Palaeothrissum" parvum BlaINVILLE, 1818. Sauvage also transfered Palaeoniscum voltzii AGASSIZ, 1833, and Palaeoniscum angustum AgASSIZ, 1833, to the genus Amblypterus AGASSIZ, 1833, considering both species to be valid. However, WoodWARD (1891) rejected the species "Palaeothrissum" inaequilobum BlAINVILLE, 1818, and "P." parvum BLAINVILLE, 1818, arguing that they were inadequately defined. Consequently, WoODWARD retained the species Amblypterus blainvillei (AgASSIZ, 1833) and Amblypterus voltzii (AgASSIZ, 1833), with the incorrect spelling, A. voltzi (ICZN, 1999, article 33.4). He also suggested that Palaeoniscum angustum AgASSIZ, 1833, was a juvenile form of Amblypterus voltzii.

After the creation of the genus Aeduella and the assignment of Palaeoniscum blainvillei (AGASSIZ, 1833) as its type species by WeSTOLL (1937), the name has been widely accepted. HEYLER (1969) later shown that Amblypterus voltzii (AGASSIZ, 1833), Amblypterus angustus (AGASSIZ, 1833) and Palaeoniscum landrioti SAUVAGE, 1890, were all subjective synonyms of Aeduella blainvillei (AGASSIZ, 1833). The statigraphic and geographic distribution of Aeduella blainvillei extends from the Upper Carboniferous (Pennsylvanian) to the Lower Permian (Cisuralian) of France, the Czech Republic, Germany and possibly Switzerland (Poplin \& DUTHEIL, 2005). Emended diagnoses of the species have been published by HEYLER (1969) and POPLIN \& DUTHEIL (2005). 

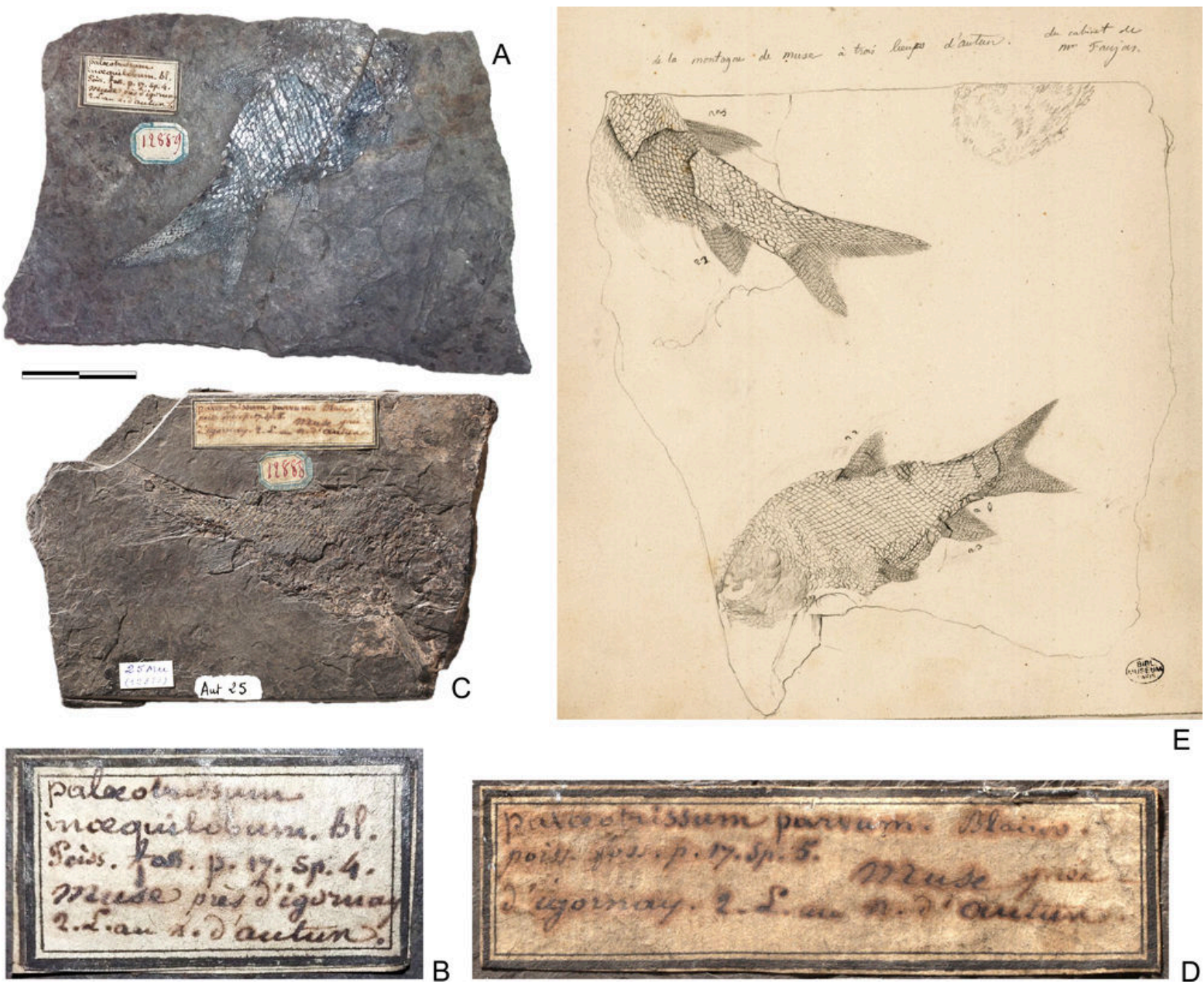

Figure 1: A and C: syntypes of Palaeothrissum inaequilobum BLAINVILLE, 1818 [nomen oblitum], from Muse, "Autunian" continental stratotype (= Asselian), Alexandre BRONGNIART's collection; A, SU.PAL.2017.0.1.16; B, detail of the label written by BRongniart "Palaeothrissum inaequilobum BL. [BLAINville] Poiss. Foss. p. 17. sp. [species] 4. Muse près d'Igornay | 2 I. [lieues] au n. [nord] d'Autun" in reference to BLAINVILLE (1818b); C, MNHN.F.AUT25; D, detail of the label written by Brongniart "Palaeothrissum parvum BLAINV. [BLAINville] Poiss. Foss. p. 17. sp. 5. Muse près d'Igornay | 2 I. [lieues] au $n$. [nord] d'Autun" in reference to BLAINVILLE (1818b). E, drawing from the CuVIER archives (Bibliothèque centrale du MNHN, Ms 540/10) showing the counterpart of the two previous specimens (credit: (C) Muséum National d'Histoire Naturelle, Paris). The slab depicted in the drawing was in the collection of BARTHÉLÉMY FAUJAS de SAINT-Fond (1741-1819). Scale bar (A, C): $30 \mathrm{~mm}$.

\section{Type series of Palaeothrissum inaequilobum BLAINVIUE, 1818, and P. parvum BLAINVIUE, 1818}

Two specimens labelled "Palaeothrissum inaequilobum BL. [BLAINVILLE]" and one specimen labelled "Palaeothrissum parvum BL. [BLAINVILLE]" from the former BRONGNIART collection are kept in the collections of the Muséum national d'histoire Naturelle, Paris (MNHN) (BRIGNON, 2014). The labels in BRONGNIART's hand indicate that they are from Muse, near Autun. MNHN.F.AUT676 (former BRONGNIART collection number 12890) and MNHN.F.AUT704 (former number 12886), on one hand, and MNHN.F.AUT25, (former number $12888)$, on the other, were therefore presumed to be syntypes of Palaeothrissum inaequilobum BLAINVILLE, 1818, and $P$. parvum BLAINVILLE, 1818, respectively. Interestingly, a drawing of a slab from Muse bearing two fish specimens in the FAUJAS de SAINT-FOND'S collection was rediscovered in the archives of Cuvier curated in the Bibliothèque centrale of the MNHN (Fig. 1.E) (BRIGNON, 2014). One of the depicted specimens (Fig. 1.E, below) is the counterpart of MNHN.F.AUT25 (Fig. 1.C-D), meaning that FAUJAS de SAINT-FOND and BRONGNIART shared parts and counterparts of the same specimens. FAUJAS de SAINT-FOND died in 1819, so that MNHN.F.AUT25 was discovered before 1819 and can confidently be regarded as one of the syntypes of Palaeothrissum parvum BLAINVILLE, 1818. 
The palaeontology collections of the Sorbonne Université (SU), formerly Université Pierre et Marie Curie, in Paris, also holds part of the Alexandre BRONGNIART's collection (BRIGNON, 2017). Since my 2014 publication (BRIGNON, 2014), I have rediscovered in $\mathrm{SU}$ an additional Muse specimen from the BRONGNIART collection (Fig. 1.A-B). It is labelled "Palaeothrissum inaequilobum BL. [BLAINVILLE]" and is the counterpart of the second specimen depicted in the drawing (Fig. 1.E, above). The SU specimen is therefore one of the syntypes of Palaeothrissum inaequilobum BLAINVILLE, 1818. A second specimen labelled "Palaeothrissum inaequilobum BL. [BLAINVILLE] de Muse" from the BronGNIART collection is also kept in SU (SU.PAL.2017. 0.1 .17 , former number 12887). The label indicates "Renaud ST AMOUR, 1833". The specimen was thus discovered or given to BRONGNIART in 1833 and therefore is not a syntype of $P$. inaequilobum. Anne-Nicolas-Joseph Renaud SAINT-AMOUR (1778-1869) was born in Saint-Amour (Jura). After his retirement from the military in 1830, he devoted himself to geological research and mine exploitation (DUFA Ÿ, 1874, p. 427).

BLAINVILLE (1818a， p. 321; 1818b, p. 17) distinguished the species $P$. inaequilobum and $P$. parvum on the observation that the two "lobes" of the caudal fin are almost equal in length in $P$. parvum whereas the upper "lobe" of $P$. inaequilobum is longer than the lower one. He also noted that $P$. parvum was slightly more elongated that $P$. inaequilobum. These distinctions are evident in the identified syntypes of both species (Fig. 1) but are, in fact, due to taphonomic distorsions. Therefore the two species are synonyms, thus confirming the conclusion of previous authors (AgASSIZ, 1833; SAUVAGE, 1890; WoOdWARd, 1891). The morphology of both specimens is typical of other specimens commonly assigned to Aeduella blainvillei (AGASSIZ, 1833) (HEYLER, 1969).

\section{Nomenclatural status of Aeduella blainvillei (AGASSIZ, 1833)}

As outlined above, Palaeoniscum blainvillei AgAssiz, 1833, is an objective junior synonym of "Palaeothrissum" inaequilobum BLAINVILLE, 1818, and "Palaeothrissum" parvum BLAINVILLE, 1818. However, replacing the specific name Aeduella blainvillei (AGASSIZ, 1833) with Aeduella inaequiloba (BLAINVILLE, 1818) or $A$. parva (BLAINVILLE, 1818 ) is not in the interest of nomenclatural stability. To mediate the Principle of Priority, Article 23.9.1 of the International Code of Zoological Nomenclature (ICZN, 1999) allows for a reversal of precedence of a junior synonym when the senior synonym has not been used as a valid name after 1899 (Article 23.9.1.1) and the junior synonym "has been used for a particular taxon, as its presumed valid name, in at least 25 works, published by at least 10 authors in the immediately preceding 50 years and encompassing a span of not less than 10 years" (Article 23.9.1.2).
To the best of my knowledge, the species names "Palaeothrissum" inaequilobum BLAINVILLE, 1818, and "Palaeothrissum" parvum BLAINVILLE, 1818, were not used as valid since 1899 thus fulfilling article 23.9.1.1 of the Code. Clearly giving priority to Aeduella blainvillei (AGASSIz, 1833), Westoll (1937, p. 554) and HeYler (1969, p. 98; 2000, p. 34-35) mentioned Palaeothrissum inaequilobum and $P$. parvum but did not considered them as valid. In BRIGNON (2014), these species were mentioned as well but were not considered as valid since their syntypes were clearly assigned to Aeduella blainvillei (AGASSIZ, 1833) (BRIGNON, 2014, Fig. 4). Furthermore, Aeduella blainvillei has been used as a valid name in at least 25 publications (see Appendix), published by at least 10 authors during the past 50 years and encompassing a span of not less than 10 years (condition 23.9.1.2). Thus Aeduella blainvillei (AGASSIZ, 1833 ) is regarded as valid, qualifying as a nomen protectum, whereas Palaeothrissum inaequilobum BLAINVILLE, 1818, and Palaeothrissum parvum BLAINVILLE, 1818, are recognized as invalid, qualifying as nomina oblita.

In his original description of Palaeoniscum blainvillei, AGASSIz (1833) referred to many specimens without any clear indication of a type. According to article 72.1.1 of the International Code of Zoological Nomenclature, all these specimens belong to the type series. These include specimens in the collections of the Museum of Strasbourg and in the cabinets of natural history of Lausanne and Neuchâtel. He also referred to specimens in the collections of Alexandre BRONGNIART and François Théophile Marie RÉGLEY (1777-1833) who inherited the collection of FAUJAS de SAINT-FOND (BRIGNON, 2015a). Syntypes of Palaeothrissum inaequilobum BLAINVILLE, 1818, and $P$. parvum BLAINVILLE, 1818, are therefore also part of the type series of Palaeoniscum blainvillei. As AGASSIZ wrote, the Muséum d'Histoire naturelle, Paris, possessed a wealth of specimens submitted by the geologist Augustin Henri de BONNARD (1781-1857). Four of the specimens from the Museum of Strasbourg are of particular interest since they were figured by AGASSIZ (1833, vol. 2, PI. 5, figs. 1-4). Three of them are still held in the palaeontology collections of the Université de Strasbourg (UNISTA) (HEYLER, 1969, p. 132-133; 2000, p. 35). These specimens are numbered UNISTA.2013.0.133 (former numbers ST1 and AUT161), UNISTA.2013.0.135 (former numbers ST3 and AUT163), and UNISTA.2013.0. 136 (former numbers ST4 and AUT164), corresponding, respectively, to the figures 2, 1 and 4 published by AgAssiz (1833, vol. 2, PI. 5) (Fig. 2). HEYLER (1969) designated specimen UNISTA. 2013.0.133 (former numbers ST1 and AUT161) as the holotype of Aeduella blainvillei. This author, when wrongly using that term, explicitly indicated that he was selecting that particular specimen from the type series illustrated by 

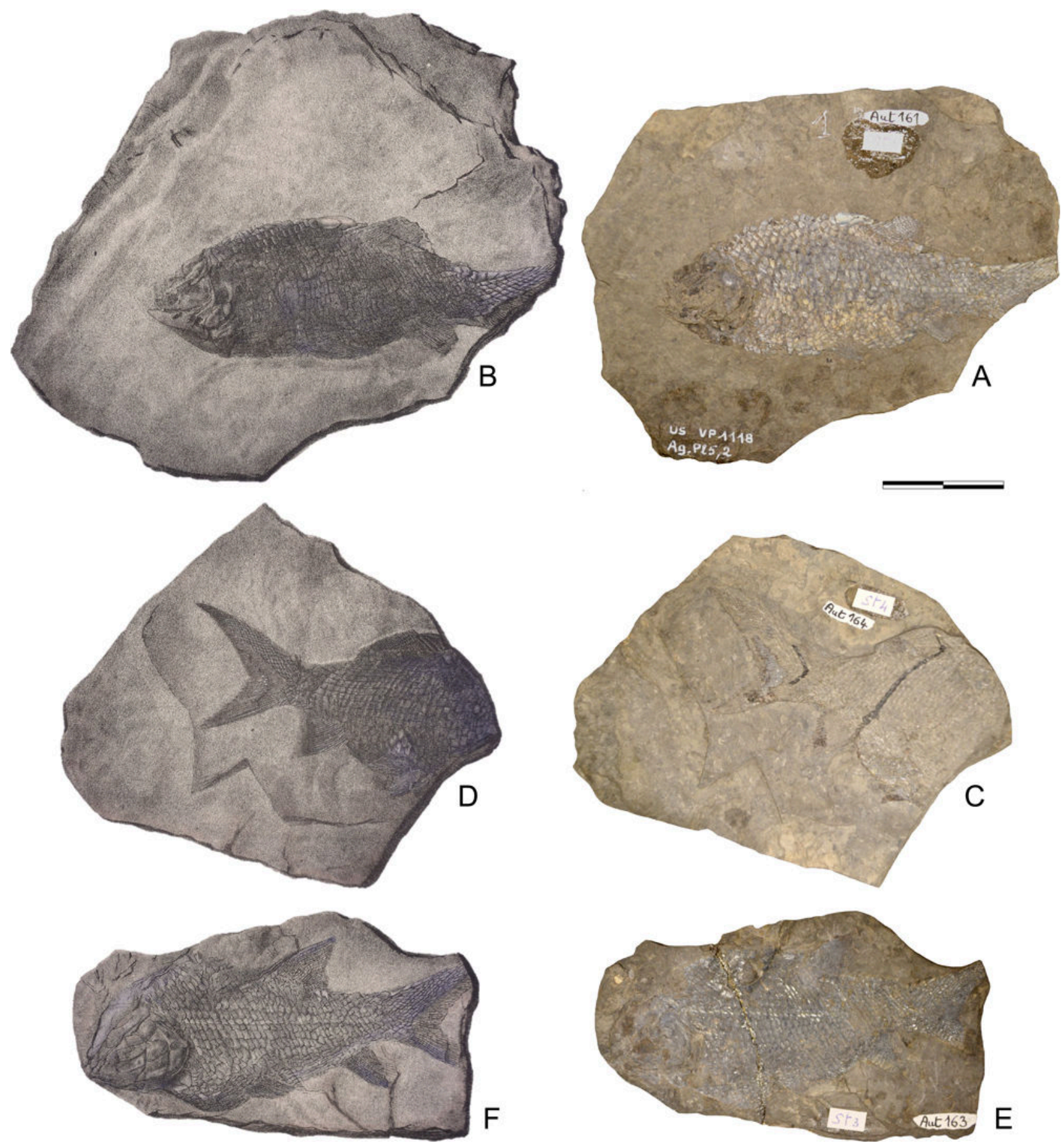

Figure 2: A, lectotype of Aeduella blainvillei (AgASSIz, 1833) [nomen protectum] from Muse, "Autunian" continental stratotype (= Asselian), UNISTA.2013.0.133. B, figure of the same published by AGASSIZ (1833, vol. 2, PI. 5, fig. 2). $\mathrm{C}$ and $\mathrm{E}$, paralectotypes of Aeduella blainvillei from Muse, Autunian" continental stratotype (= Asselian); C, UNISTA.2013.0.136. D, figure of the same published by AGASSIZ (1833, vol. 2, PI. 5, fig. 4). E, UNISTA.2013.0.135. F, figure of the same published by AGASSIz (1833, vol. 2, PI. 5, fig. 1). Scale bar: $30 \mathrm{~mm}$.

AgASSIZ to serve as the name-bearing type. According to Article 74.5 of the Code, this act can be considered as a lectotype designation. All the other specimens mentioned by AGASSIZ in his original description therefore become paralectotypes in accordance with Article 74.1 of the Code. Known paralectoypes are UNISTA.2013.0.135 (AgAssiz, 1833, vol. 2, Pl. 5, fig. 1) (Fig. 2.E),
UNISTA.2013.0.136 (AGASSIZ, 1833, vol. 2, PI. 5, fig. 4) (Fig. 2.C), MNHN.F.AUT704 (BRONGNIART collection number 12886), MNHN.F.AUT676 (BRONGNIART collection number 12890), MNHN.F. AUT25 (BRONGNIART collection number 12888) (Fig. 1.C) and SU.PAL.2017.0.1.16 (BRONGNIART'S collection number 12889) (Fig. 1.A). 


\section{Systematic palaeontology}

Class Osteichthyes HUXLEY, 1880

Subclass Actinopterygii COPE, 1887

Order Aeduelliformes HeYLeR, 1969

Family Aeduellidae RoMer, 1945

Genus Aeduella Westoll, 1937

Type species.- by monotypy: Palaeoniscum blainvillei AGASSIZ, 1833 (nomen protectum), junior synonym of Palaeothrissum inaequilobum BLAINVILLE, 1818, and Palaeothrissum parvum BLAINVILLE, 1818 (nomina oblita).

Statigraphic and geographic distributions of the genus.- Upper Carboniferous (Pennsylvanian) and Lower Permian (Cisuralian) from France, the Czech Republic, Germany and Switzerland (PoPLIN \& DUTHEIL, 2005).

\section{Aeduella blainvillei (AgASSIz, 1833)}

Type material.- lectotype: UNISTA.2013.0.133 (Fig. 2.A); known paralectoypes: UNISTA.2013.0. 135 (Fig. 2.E), UNISTA.2013.0.136 (Fig. 2.C), MNHN.F.AUT704 (BRONGNIART's collection number 12886) (BRIGNON, 2014, Fig. 4.A), MNHN.F. AUT676 (BRONGNIART's collection number 12890), MNHN.F.AUT25 (BRONGNIART's collection number 12888) (Fig. 1.C), SU.PAL.2017.0.1.16 (BRON GNIART's collection number 12889) (Fig. 1.A).

Type locality and horizon.- Muse (Saône-etLoire), Schistes bitumineux (Muse formation), continental regional Autunian stratotype, Asselian stage.

Diagnosis.- see HeYler (1969) and Poplin \& DUTHEIL (2005).

\section{Conclusion}

In conclusion, the type species by monotypy of the genus Aeduella WESTOLL, 1937 (Actinopterygii, Aeduelliformes, Aeduellidae), is Palaeoniscum blainvillei AGASSIZ, 1833 (nomen protectum), junior synonym of Palaeothrissum inaequilobum BLAINVILLE, 1818, and Palaeothrissum parvum BLAINVILLE, 1818 (nomina oblita). This nomenclatural act promotes stability and retains the widely used and accepted name Aeduella blainvillei (AGASSIZ, 1833) as a valid one.

\section{Acknowledgements}

The author is grateful to Isabelle ROUGET, Stéphane Jouve (SU), Gaël CLÉment and Alan PRADEL (MNHN) for providing access to the collections under their care. He thanks L. CAREZ (MNHN/CNRS) and Kévin JANNEAU (UNISTA) for providing photographs of specimens, and Lionel CAVIN and Stanislav ŠTAMBERG for their helpful comments. Finally, he also thanks the central library of the MNHN for giving him the permission to reproduce the drawing Ms 540/10.

\section{Bibliographic references}

Agassiz J.-L.-R. (1833).- Recherches sur les poissons fossiles, $1^{\mathrm{e}}$ livraison.- Petitpierre et Prince (texte) et $\mathrm{H}$. Nicolet (planches), Neuchâtel, vol. 1: p. [i]-xii, [1]-16 (title page for volume 1 dated 1833, first version of the text), Pls. AG; vol. 2: p. [1]-48, Pls. A-C, 1-7; vol. 4: p. 17-32, Pls. A, 1, 2; vol. 5, $1^{\mathrm{e}}$ partie: p. 17-24, PIs. A, 1, 2.

AgASSIZ J.-L.-R. (1834).- Recherches sur les poissons fossiles, $2^{\mathrm{e}}$ livraison. Petitpierre et Prince (texte) et H. Nicolet (planches), Neuchâtel, vol. 1: 17-40 (first version of the text); vol. 2: 49-84, Pls. F, 11, 12, 15, 16, 22, 26-30, 32, 33, 40; vol. 4: Pls. 3-6; vol. 5, $1^{\text {e }}$ partie: 2532; Pls. 3-6; feuilleton additionnel: [1]-20; liste des souscripteurs: [1]-2.

Blainville H.M. de (1818a).- Poissons fossiles. In: Nouveau Dictionnaire d'Histoire Naturelle appliquée aux arts, à l'agriculture, à l'économie rurale et domestique, à la médecine, etc. par une société de naturalistes et d'agriculteurs, tome 27, (Pla - Por).- Deterville, Paris, p. 310395.

Blainville H.M. de (1818b).- Sur les ichthyolites ou les poissons fossiles.- Extrait du Nouveau Dictionnaire d'Histoire Naturelle, Paris, $91 \mathrm{p}$.

Blieck A., Malvesy T., Candilier A.-M., Cloutier R. \& Poplin C. (1999).- Les collections du Musée d'Histoire naturelle de Lille. II. Vertébrés paléozoïques.- Annales de la Société Géologique du Nord ( $2^{\mathrm{e}}$ série), Lille, vol. 7, p. 87-128.

BOY J.A. \& SCHINDLER T. (2000).- Ökostratigraphische Bioevents im Grenzbereich Stephanium/Autunium (höchstes Karbon) des SaarNahe-Beckens (SW-Deutschland) und benachbarter Gebiete.- Neues Jahrbuch für Geologie und Paläontologie, Abhandlungen, vol. 216, p. 89-152.

BRIGNON A. (2014).- Les recherches paléoichthyologiques et géologiques sur le gisement permien de Muse près d'Autun (Saône-etLoire) au début du $\mathrm{XIX}^{\mathrm{e}}$ siècle.- Bulletin de la Société Géologique de France, vol. 185, no. 4, p. 233-252.

BRIgnon A. (2015a).- FAujas de SAINT-Fond, ReinWARDT, CUVIER et les poissons fossiles du Crétacé de la "Montagne Saint-Pierre" de Maastricht (Pays-Bas).- Geodiversitas, vol. 37, p. 59-77.

BRIgnon A. (2015b).- Le "Pygopterus" bonnardi AgAssiz, 1833 (Xenacanthidae) de l'Autunien de Muse (Saône-et-Loire) : Premier requin paléozoïque découvert en France.- Fossiles : Revue française de Paléontologie, no. 23, p. 1520.

BRIGNON A. (2017).- The earliest discoveries of articulated fossil fishes (Actinopterygii) in the United States: A historical perspective.- American Journal of Science, vol. 317, 216-250. 
BÜRGIN T. (1990).- Palaeonisciden (Osteichthyes: Actinopterygii) aus dem Unteren Rotliegenden (Autunien) der Nordschweiz.- Eclogae geologicae Helvetiae, vol. 83, 813-827.

Cope E.D. (1887).- ZitTEL's Manual of Palaeontology.- American Naturalist, vol. 21, p. 10141019.

DiETZE K. (1999).- Paramblypterus duvernoyi (Actinopterygii): Skull morphology and intraspecific variation, and its implications for the systematics of paramblypterid fishes.- Journal of Vertebrate Paleontology, vol. 19, p. 247262.

DiETZE K. (2000).- A revision of paramblypterid and amblypterid actinopterygians from Upper Carboniferous-Lower Permian lacustrine deposits of Central Europe. - Palaeontology, vol. 43, p. 927-966.

DUFAŸ C.-J. (1874).- Biographie des personnages notables du département de I'Ain, Galerie militaire de I'Ain.- L. Grandin, Bourg, 511 + [1] $p$.

FALCONNET J. (2014).- An evaluation of French amniote diversity through the PennsylvanianCisuralian boundary.- Annales de Paléontologie, vol. 100, p. 119-130.

Gand G., Pellenard P., Galtier J., Broutin J. \& STEYER J.-S. (2017).- Le stratotype Autunien du bassin d'Autun (Bourgogne-France) : Évolution de la stratigraphie et des âges.- Bulletin de la Société d'Histoire Naturelle d'Autun, vol. 211, p. 19-36.

GAND G., Stéyer S. \& Chabard D. (2011).- Reprise des fouilles paléontologiques dans un gîte bourguignon célèbre : Les "schistes bitumineux" de l'Autunien de Muse (bassin d'Autun). Bilan 2010 et perspective.- Revue Scientifique Bourgogne-Nature, vol. 12, p. 10-29.

GotTfried M.D. (1987).- A Pennsylvanian aeduelliform (Osteichthyes, Actinopterygii) from North America with comments on aeduelliform interrelationships.- Paläontologische Zeitschrift, vol. 61, p. 141-148.

HeYLeR D. (1969).- Vertébrés de l'Autunien de France.- Cahiers de Paléontologie, Éditions du Centre National de la Recherche Scientifique, 259 p. (52 Pls.).

HeYLeR D. (1991).- Sur la présence de l'espece Aeduella blainvillei (Pisces, Actinopterygii) dans le Permien inférieur de la Sarre.- Bulletin de la Société d'Histoire Naturelle d'Autun, vol. 135 , p. 17-32.

HeYLER D. (2000).- Les actinoptérygiens stéphaniens et autuniens du Massif central (France) dans les collections du M.N.H.N. (Paris) et du Muséum d'Autun : Compléments, mises au point, bilan.- Bulletin de la Société d'Histoire Naturelle d'Autun, vol. 169, p. 7-44.
HeYler D. \& Pacaud G. (1978).- Nouveautés paléontologiques et géologiques dans l'Autunien du Bassin d'Autun.- Société d'Histoire Naturelle et des Amis du Muséum d'Autun, no. 85, p. 12-23.

Heyler D. \& Poplin C. (1983).- Actinoptérygiens du Stéphanien de Montceau-les-Mines (Saôneet-Loire, France).- Palaeovertebrata, vol. 13, p. 33-50.

HeYleR D. \& Poplin C. (1988).- The fossils of Montceau-les-Mines.- Scientific American, vol. 259, p. 104-111.

Heyler D. \& Poplin C. (1990).- Les vertébrés autuniens de Bruxières-les-Mines.- Bulletin du Muséum d'Histoire naturelle ( $4^{\mathrm{e}}$ série), Paris, vol. 12 , p. 225-239.

HUXLEY T.H. (1880).- On the applications of the laws of evolution to the arrangement of the Vertebrata and more particularly of the Mammalia.- Proceedings of the Zoological Society of London, year 1880, p. 649-662.

International Commission on Zoological Nomenclature - ICZN (1999).- International Code of Zoological Nomenclature, $4^{\text {th }}$ edition.- International Trust for Zoological Nomenclature, London, xxix $+306 \mathrm{p}$.

MARTEAU P. (1983).- Le bassin permo-carbonifère d'Autun : Stratigraphie, sédimentologie et aspects structuraux.- Bureau de recherches géologiques et minières, Service géologique national, $198 \mathrm{p}$.

Pellenard P., Gand G., Schmitz M., Galtier J., Broutin J. \& Steyer J.-S. (2017).- High-precision $\mathrm{U}-\mathrm{Pb}$ zircon ages for explosive volcanism calibrating the NW European continental Autunian stratotype.- Gondwana Research, vol. 51, p. $118-136$.

Poplin C. (2001).- Le genre Bourbonnella (Actinopterygii, Aeduellidae) : Révision et description d'une nouvelle espèce du Stéphanien (Carbonifère supérieur) de Montceau-les-Mines (Massif Central, France).- Annales de Paléontologie, vol. 87, p. 231-248.

Poplin C. \& DUTHEIL D.B. (2005).- Les Aeduellidae (Pisces, Actinopterygii) carbonifères et permiens : Systématique et étude phylogénétique préliminaire.- Geodiversitas, vol. 27, no. 1, p. 17-33.

QuenstedT F.A. (1852).- Handbuch der Petrefaktenkunde.- H. Laupp Verlag, Tübingen, iv + 793 p. (62 Pls.).

RAT P. (1972).- Bourgogne Morvan, guides géologiques régionaux.- Masson $\& C^{i e}$, Paris, $174 \mathrm{p}$.

ROMER A.S. (1945).- Vertebrate Paleontology.University of Chicago Press, Chicago, ix + $687 \mathrm{p}$.

Sauvage H.-E. (1890).- Bassin houiller et Permien d'Autun et d'Epinac, fascicule III, poissons fossiles.- Études des gîtes minéraux de la France, 
Imprimerie Nationale, Paris, [iv] + 31 p. (5 Pls.).

SCHINDLER T. (2003).- Kurzer Bestimmungsschlüssel für die im mitteleuropäischen Rotliegend (Stephanium D., Autunium und Saxonium) auftretenden Chondrosteer-Familien (Osteichthyes, Actinopterygii; Ober-Karbon Unter-Perm).- Mitteilungen der Pollichia, vol. 90, p. 7-18.

ŠTAMBERG S. (1981).- Some further results of the study of Permocarboniferous fishes from North-eastern Bohemia.- Acta Musei Reginaehradecensis s. A: Scientiae Naturales, vol. 16, p. 107-124.

ŠTAMBERG S. (2006).- Carboniferous-Permian actinopterygian fishes of the continental basins of the Bohemian Massif, Czech Republic: An overview.- Geological Society, London, Special Publications, vol. 265, p. 217-230.

ŠTAMBERG S. (2010).- A new aeduellid actinopterygian from the Lower Permian of the Krkonoše Piedmont Basin (Bohemian Massif) and its relationship to other Aeduellidae.- Bulletin of Geosciences, vol. 85, p. 183-198.

ŠtAMBERG S. (2013a).- Knowledge of the Carboniferous and Permian actinopterygian fishes of the Bohemian Massif - 100 years after Antonín Frič.- Acta Musei Nationalis Pragae, Series B - Historia Naturalis, vol. 69, p. 159-182.

ŠtAMBERG S. (2013b).- Aeduellid fishes (Actinopterygii) of the Bohemian Massif (Czech Republic) across the Carboniferous-Permian boundary. In: LUCAS S.G., DiMICHELE W.A., BARRICK J.E., SCHNEIDER J.W. \& SPIELMANN J.A. (eds.), The Carboniferous-Permian Transition.New Mexico Museum of Natural History and Science, Bulletin, number 60, p. 417-422.

ŠTAMBERG S. (2016a).- Actinopterygians of the Stephanian sediments of the Krkonoše Piedmont Basin (Bohemian Massif) and their palaeobiogeographic relationship.- Bulletin of Geosciences, vol. 91, p. 169-186.

ŠTAMBERG S. (2016b).- A new actinopterygian species of Igornichthys HEYLER, 1972 from the Permian of the Krkonoše Piedmont Basin
(Bohemian Massif, Czech Republic), and its relationship to the actinopterygians of other European Permo-Carboniferous basins.- Geodiversitas, vol. 38, p. 475-488.

SteYer J.S., Escuillié F., POuillon J.-M., Broutin J., Debriette P., Freytet P., Gand G., Poplin C., Rage J.-C., Rival J., SChneider J.W., ŠtamberG S., Werneburg R. \& Cuny G. (2000).- New data on the flora and fauna from the ?uppermost Carboniferous-Lower Permian of Buxières-lesMines, Bourbon I'Archambault Basin (Allier, France); a preliminary report.- Bulletin de la Société Géologique de France, vol. 171, p. 239-249.

TRAQUAIR R.H. (1877).- On the Agassizian genera Amblypterus, Palaeoniscus, Gyrolepis, and Pygopterus.- Quarterly Journal of the Geological Society, vol. 33, p. 548-578.

Westoll T.S. (1937).- On a remarkable fish from the Lower Permian of Autun, France.- Annals and Magazine of Natural History, Series 10, vol. 19 , p. 553-578

WoODWARD A.S. (1891).- Catalogue of the fossil fishes in the British Museum, Part II.- British Museum (Natural History), London, xli +567 p. (16 Pls.).

\section{Appendix}

A list of 30 publications by 33 different authors published in the last 50 years, using Aeduella blainvillei (AGASSIZ, 1833) as a valid name to fulfill the requirements of Article 23.9.1.2 of the International Code of Zoological Nomenclature (ICZN, 1999):

BLIECK et al., 1999; Boy \& SCHINDLER, 2000, p. 124; BRIGNON, 2014, 2015b; BÜRGIN, 1990; DiETZE, 1999, 2000; GAND et al., 2017; GotTFRIED, 1987; HEYLER, 1969, 1991, 2000; HEYLER \& PACAUD, 1978; HEYLER \& POPLIN, 1983, 1988, 1990; Marteau, 1983, p. 61; Pellenard et al., 2017; POPLIN, 2001; POPLIN \& DUTHEIL, 2005; RAT, 1972, p. 152; SCHINDLER, 2003; ŠTAMBERG, 1981, 2006, 2010, 2013a, 2013b, 2016a, 2016b; STEYER et al., 2000. 